\title{
A Critical Introduction to Khomeini
}

\author{
Arshin Adib-Moghaddam, ed. \\ New York: Cambridge University Press, 2014. 306 pages.
}

Ayatollah Ruhollah Khomeini (1902-89) is undoubtedly one of the twentieth century's key international revolutionary figures whose role is definitive to modern Iranian history. A massive amount of scholarship has been produced in Iran about him; this is not the case, however, in the English-speaking world. This publication by a collection of eminent scholars of Iranian studies, therefore, examines the critical impact of his political thought and religious philosophy within and beyond Iran.

In "Introduction," editor Arshin Adib-Moghaddam provides a brief summary of Khomeini's political life before, during, and after the revolution. In his view, the Islamic Republic's revolutionary discourse not only triggered unprecedented sociopolitical changes, but also influenced the subjectivity of Iranian citizens. Moreover, he maintains that the two pillars of the ayatollah's political thought were a "strong state" and "independence from foreign influences," which are still adamantly pursued today (p. 15).

Fakhreddin Azimi, in "Khomeini and the "White Revolution,"” looks at the social context of his rise to prominence in the pre-revolutionary decades. With the dissolution of Reza Shah's autocratic rule in 1941, secular and leftist discourses gained enough momentum to threaten the religious establishment. Despite these changes, the leading Shi' $i$ ulema maintained a quietist stance until the middle of twentieth century (p. 19). During the 1960s, Khomeini initiated his rigorous anti-Shah political activity by combining "a stern moralism on gender issues and sociopersonal freedoms" with "forceful professions of 
opposition to tyranny and adherence to constitutional principles and the rights and liberties they entailed" (p. 27). Azimi asserts that the Islamic Revolution's success was due not only to Khomeini's political activities, but also to the absence of any viable oppositional alternatives and the regime's undermining of constitutionalism by its autocratic reform agenda (p. 42).

In "The Rise of Khomeinism: Problematizing the Politics of Resistance in Pre-Revolutionary Iran," Mojtaba Mahdavi focuses on the revolutionary phase of Khomeini's life (1971-79) and, drawing upon Karl Marx's thoughts regarding the interaction between social structures and actors, points out the social, political, economic, and religious forces that shaped the Islamic Revolution. Mahdavi warns against conceptualizing Islamic revolutionary discourse as "essentialist, monolithic, wholesaled, and unified" and maintains that "the revolutionary movement was made of a populist coalition of left, right, religious, and secular trends as well as liberal and socialist groups" (p. 61).

In "Wilayat al-Faqih and the Meaning of Islamic Government," Amr GE Sabet examines how this concept evolved in Khomeini's religio-political worldview. Sabet cautions readers not to accept the Westerners' observation that the Islamic Republic is theocratic, religiously dictatorial, or dominated by the rule of the mullahs because such analyses "oversimplify highly complex issues and reflect an ideological prejudice and/or lack of comprehension" (p. 69). In his view, the system of governance born out of this concept was not exclusively theocratic, democratic, or authoritarian; rather, it was a combination of all. Ali Rahnema, in "Ayatollah Khomeini's Rule of the Guardian Jurist: From Theory to Practice," traces the evolution of this same concept from the ayatollah's first theoretical articulation of it during his exile in Iraq until its practical implementation in the constitution of the Islamic Republic. Rahnema asserts that he did not advocate it after the revolution unilaterally, but that it was in fact "the inflexibility and adamancy of honest, ethical, democratic and highly principled men" that "prevented Iran from having a constitution without the Rule of the Guardian Jurist" (p. 114).

L. A. Reda, in "Khatt-e Imam: The Followers of Khomeini's Line," contends that Khomeini's interpretation of the Shi' is' history of rebellion against oppression, exemplified by Imam Hussein as well as his anti-imperialism stance, resonated strongly with the students and the clerics during the 1960s and 1970s. Therefore these groups, who were very significant before and after the revolution, identified themselves as "Imam Khomeini's line" after the establishment of the Islamic Republic (p. 115). They stormed the American Embassy on November 4, 1979, and took fifty-two American nationals hostage 
as an anti-imperialist move in line with Khomeini's revolutionary message (p. 127). The clergy then tried to export the Islamic revolution after his death, arguing that it had proved Islam's effectiveness as a political ideology in the modern world (p. 133).

Mehran Kamrava, in "Khomeini and the West," surveys the ayatollah's interpretation of the West during various stages of his political career. In Kamrava's view, his conceptualization of the West, which occupied a central position in his religio-political thought, was not entirely unique; rather, it was more consonant with the standard position of the Iranian left toward the West's imperial machinations in the Third World. Furthermore, Khomeini did not maintain a constant antagonistic stance toward the West. While he criticized it vehemently in his political pronouncements, the newly formed Islamic Republic needed the West economically because the structure of the Iranian economy, inherited from the Pahlavis, relied upon it (p. 150).

In "Gendered Khomeini," Azadeh Kian examines his perception of women and their role in society from 1962 to 1989 . She argues that Khomeini did not adhere to a conservative interpretation and followed a more pragmatic policy in dealing with gender issues. Therefore, his changing understanding of women's social role has left its imprint on Iranian politics to this day and created "a widening gap between the social, demographic and cultural realities of women on the one hand and the laws and institutions of the revolutionary years on the other" (p. 190).

In "Hidden Khomeini: Mysticism and Poetry," Lloyd Ridgeon discusses the influence of mysticism and Sufi thought on Khomeini's religio-political views. He maintains that "the idea of mystical union" is observable in Khomeini's writings in 1930s, but that he remained silent regarding Sufi tendencies until 1980s when he published a collection of his ghazals (sonnets) and demonstrated mystical themes. The mystical aspects of his thought have not been discussed sufficiently in Iran, mainly because within the Islamic tradition there is an incongruity between the faqi $h$ who gains authority by his ability to "determine the probable will of the Hidden Imam" and the mystic who communicates with the divine directly (p. 193). Moreover, Ridgeon warns that Khomeini's observable mystical tendencies remained strictly theoretical and confined within the acceptable norms of the Twelver Shi'ism (p. 210).

In "The Divine, the People, and the Faqih : On Khomeini's Theory of Sovereignty," Behrooz Ghamari-Tabrizi looks at the evolution of velayat- $i$ faqih during Khomeini's long political career. He maintains that due to the ayatollah's utilitarian and pragmatic approach to politics in general and to this 
concept in particular, many scholars believe that his political thought is contradictory and indeterminate (p. 211). However, Ghamari-Tabrizi posits that Khomeini did not maintain the same political stance for his almost sixty years of political activity, for his political philosophy naturally evolved along with Iran's changing sociopolitical circumstances and his own changing interpretations of politics (p. 212). He did not formulate velayat-i faqih completely before the revolution, and it was only with the consolidation of the new republic's Islamic ideology, as well as under the influence of nationalist, socialist, and Islamic elements, that he further elaborated upon it and made it a political ideology (p. 238).

In her "Khomeini's Legacy on Women's Rights and Roles in the Islamic Republic of Iran," Arzoo Osanloo bases her arguments on the assumption that the Islamic Republic indisputably implemented and followed Khomeini's teachings in general and his political decisions in particular; however, she only references one of his many books. Thus she provides a very essentialist portrayal of his legacy in contemporary Iran. Sadegh Zibakalam, in "To Rule or Not to Rule? An Alternative Look at the Political Life of Ayatollah Khomeini between 1960 and 1980," challenges the prevalent theory of both his supporters and opponents that he had a clear-cut definition of velayat-i faqih and planned its implementation from the beginning of his political career. In Zibakalam's view, during the prerevolutionary uprising against the Shah the foremost dissident movements were socialist, secular, and Marxist. Given this reality, there was no opportunity or penchant on Khomeini's part to promote an Islamic system of governance (p. 259). Moreover, there was no mention of velayat-i faqih in the first draft of the Islamic Constitution of 1980, which was prepared under his supervision (p. 274).

In "Khomeini and the Decolonization of the Political," S. Sayyid locates the ayatollah's revolutionary activities within a broader context of politicizing and depoliticizing Islam as an identity and as an ideology against the colonial/ western powers in the region, thereby offering an essentialist picture of Khomeini vs. the Pahlavi state. By throwing Khomeini and the Pahlavi state in a binary of Islam vs. Eurocentricism, his article precludes any discussion of the existing complexities on both sides of this divide. In fact, he ignores not only the book's other chapters but also numerous works by scholars in the field who address such complexities.

In "Contentious Legacies of the Ayatollah," Babak Rahimi examines how Khomeini's political legacy has been interpreted and executed in the postrevolution state's structure. He argues that Khomeini followed two principal goals in his political thought: the formation of "a strong shariah-based con- 
stitution" whereby the government protected the nation and the ulema supervised execution of the law, and the foundation of a strong centralized state legitimized through democratic apparatuses (pp. 295-96). In Rahimi's view, the Islamic Republic's conservative and reformist factions in recent decades have drawn upon either of these elements to promote their own respective policies.

To conclude, this volume provides fresh perspectives on the life and legacy of Ayatollah Khomeini and is an indispensable contribution to the history of modern Iran and Middle East.

Mojtaba Ebrahimian $\mathrm{PhD}$ Candidate/Language Instructor, Persian Literature and Iranian Culture School of Middle Eastern and North African Studies The University of Arizona, Tucson, AZ 